\title{
Poetic Critique
}




\section{WeltLiteraturen/ World Literatures}

Schriftenreihe der Friedrich Schlegel Graduiertenschule für literaturwissenschaftliche Studien

Herausgegeben von

Jutta Müller-Tamm, Andrew James Johnston, Anne Eusterschulte, Susanne Frank und Michael Gamper

Wissenschaftlicher Beirat

Ute Berns (Universität Hamburg), Hans Ulrich Gumbrecht (Stanford University), Renate Lachmann (Universität Konstanz), Ken'ichi Mishima (Osaka University), Glenn W. Most (Scuola Normale Superiore Pisa), Jean-Marie Schaeffer (EHESS Paris), Stefan Keppler-Tasaki (University of Tōkyō), Janet A. Walker (Rutgers University), David Wellbery (University of Chicago), Christopher Young (University of Cambridge)

\section{Volume 19}




\section{Poetic Critique}

Encounters with Art and Literature

Edited by

Michel Chaouli, Jan Lietz, Jutta Müller-Tamm, and Simon Schleusener

\section{DE GRUYTER}


ISBN 978-3-11-068857-3

e-ISBN (PDF) 978-3-11-068871-9

e-ISBN (EPUB) 978-3-11-068881-8

ISSN 2198-9370

DOI https://doi.org/10.1515/9783110688719

\section{(c) BY-NC-ND}

This work is licensed under a Creative Commons Attribution-NonCommercial-NoDerivatives 4.0 International License. For details go to https://creativecommons.org/licenses/by-nc-nd/4.0/

\section{Library of Congress Control Number: 2020951273}

\section{Bibliographic information published by the Deutsche Nationalbibliothek} The Deutsche Nationalbibliothek lists this publication in the Deutsche Nationalbibliografie; detailed bibliographic data are available on the Internet at http://dnb.dnb.de.

(C) 2021 Michel Chaouli, Jan Lietz, Jutta Müller-Tamm, and Simon Schleusener, published by Walter de Gruyter GmbH, Berlin/Boston The book is published open access at www.degruyter.com. Cover: Designed by Jürgen Brinckmann, Berlin, using a graphic by Anne Eusterschulte Printing and binding: $\mathrm{CPI}$ books $\mathrm{GmbH}$, Leck

www.degruyter.com 
We thank the Einstein Foundation Berlin for its generous support of the publication of this volume. 
